\title{
CATUR PURUSA ARTHA LENSA DEKONSTRUKSI DEFINISI PAJAK YANG BERKEADILAN
}

\author{
I Nyoman Darmayasa ${ }^{1)}$ \\ Yuyung Rizka Aneswari ${ }^{2)}$ \\ ${ }^{1}$ Akuntansi, Politeknik Negeri Bali, Jalan Kampus Bukit Jimbaran, \\ Kuta Selatan, Badung, Bali, $80364^{1)}$ \\ ${ }^{2}$ Akuntansi, STIE Kesuma Negara Blitar, Jalan Mastrip No.59, \\ Kepanjen Kidul, Blitar, Jawa Timur, 661112) \\ nyomandarmayasa@pnb.ac.id ${ }^{1)}$
}

\begin{abstract}
.
Catur Purusa Artha Lens of Deconstruction Equitable Tax Definition. The study aims to deconstruct the definition of tax with Catur Purusa Artha (CPA) lens. Research using postmodern paradigm focused on modernity disagreement of tax definition based on act. Tax definition for the result of deconstruction namely Dharma in the form of funds contribution that conducted sincerely from individual's or entity's Artha to the state which will be distributed based on Kama for the purposes of the state for the welfare of the people. The essence of the deconstruction definition provide a sense of equitable and stimulation of tax compliance.
\end{abstract}

Key word: Catur Purusa Artha (CPA), Deconstruction Tax Definition, Equitable, Tax Compliance, Local Wisdom, Postmodern

\begin{abstract}
Abstrak
Catur Purusa Artha Lensa Dekonstruksi Definisi Pajak Yang Berkeadilan. Penelitian bertujuan mendekonstruksi definisi pajak dengan lensa Catur Purusa Artha (CPA). Penelitian menggunakan paradigma postmodern fokus pada ketidaksetujuan modernitas definisi pajak berdasarkan UU. Definisi pajak hasil dekonstruksi yaitu pajak merupakan Dharma dalam bentuk kontribusi uang yang dilakukan secara tulus ikhlas yang berasal dari Artha orang pribadi atau badan kepada negara yang didistribusikan bagi sebesarbesar kemakmuran rakyat berlandaskan Kama. Esensi definisi pajak hasil dekonstruksi memberikan rasa keadilan dan stimulasi kepatuhan pajak.
\end{abstract}

Kata kunci: Catur Purusa Artha (CPA), Dekonstruksi Definisi Pajak, Keadilan, Kepatuhan Pajak, Kearifan Lokal, Postmodern

\section{PENDAHULUAN}

Pajak merupakan sumber penerimaan terbesar dalam APBN Indonesia. Sehingga pemberian definisi yang tepat terhadap pajak merupakan hal yang penting. Melalui definisi akan membawa arah pemaknaan pada masing-masing individu sebagai Wajib Pajak (WP). Definisi pajak merupakan cerminan mengenai sifat, tujuan, dasar, dan mekanisme pemungutan pajak. Makna yang dipahami oleh WP tersebut akan sangat berpengaruh besar dalam pilihan tindakan WP untuk mematuhi regulasi perpajakan atau sebaliknya. 
Definisi pajak telah dituangkan dalam UU No. 28 tahun $2007^{1}$. Namun definisi ini perlu dikaji secara mendalam, sebab definisi yang tertuang dinilai sarat dengan unsur modernitas. Definisi pajak ini lebih menekankan pada aspek materialisme yang mengarusutamakan uang, hanya untuk tujuan ekonomi yakni memperoleh penerimaan pajak sebesar-besarnya. Definisi tersebut juga menunjukkan esensi adanya pemaksaan dalam pemungutannya.

Pajak merupakan sumber pendapatan yang harus dipungut sesuai dengan aturan yang jelas. Artinya semua pemungutan pajak tertuang dalam aturan yang diformulasikan dalam undang-undang dan segala aturan pelaksanaannya. Sesuai dengan pernyataan No Taxation Without Representation dan Taxation Without Representation is Robbery. Artinya segala pungutan yang kaitannya dengan pajak harus diatur dengan jelas dan yang paling utama definisi pajak juga harus tertera dengan jelas. Pajak yang dipungut tanpa adanya aturan dapat disamakan sebagai pungutan liar (Aneswari, Darmayasa, dan Yusdita 2015).

Mengutip Franklin (1706-1790) ${ }^{2}$ bahwa "satu-satunya hal yang pasti di dunia ini adalah kematian dan pajak". Pajak disamakan dengan kematian, sebab kematian adalah sesuatu yang tak dapat dihindari, begitu pula dengan pajak. Pandangan tersebut memberikan arti, bahwa kita tidak bisa menghindar untuk bayar pajak. Segala aktivitas yang ada nilai tambahnya merupakan objek pajak. Setiap kegiatan ekonomi ada potensi pajak yang harus dibayar, setiap tambahan kemampuan ekonomis menjadi objek pajak yang diatur dalam hukum pajak materiil yaitu UU $\mathrm{PPh}^{3}$. Sedangkan, tata cara melaksanakan hukum materiil diatur dalam hukum pajak formil. Melalui hukum pajak formil yang terdapat dalam UU $\mathrm{KUP}^{4}$ (Mardiasmo 2013:5) untuk pertama kalinya memuat tentang definisi pajak.

Definisi pajak saat ini lebih menekankan pada aspek pemaksaan. Pemaksaan otoritas perpajakan diibaratkan seperti penguasa yang bisa memaksa WP untuk membayar pajak. Beberapa pihak telah mulai merasakan pentingnya untuk melakukan dekonstruksi definisi pajak. Salah satunya melalui kongres pajak sedunia sebagaimana tertulis dalam Rosdiana dan Irianto (2014:2) pada bulan September 2005 yang diselenggarakan di Buenos Aires, Argentina. Hasil kongres pajak tersebut menghasilkan diskursus-diskursus yang berkembang untuk merekonstruksi definisi pajak.

Artikel maupun penelitian yang mengajukan sebuah konsep dekonstruksi definisi pajak relatif sedikit. Sebab definisi pajak terutama yang telah tertuang dalam UU dianggap sebagai sesuatu yang telah mapan dan hanya perlu diikuti dan ditaati.

Definisi Pajak sesuai dengan UU No. 28 Tahun 2007 tentang Ketentuan Umum dan Tata Cara Perpajakan pasal 1 (1), pajak adalah kontribusi wajib kepada negara yang terutang oleh orang pribadi atau badan yang bersifat memaksa berdasarkan Undang-Undang, dengan tidak mendapatkan imbalan secara langsung dan digunakan untuk keperluan negara bagi sebesar-besarnya kemakmuran rakyat.

2 Benjamin Franklin adalah seorang tokoh Amerika Serikat yang terkenal dan telah meninggalkan banyak karya di dalam hidupnya, lahir pada 17 Januari 1706 di Boston dan meninggal pada 17 April 1790 di Philadelphia.

3 Undang-Undang No. 36 Tahun 2008 perubahan keempat atas Undang-Undang Nomor 7 Tahun 1983 tentang Pajak Penghasilan, selanjutnya dalam penelitian ini disebut UU PPh.

4 Undang-Undang No. 28 Tahun 2007 perubahan ketiga atas Undang-Undang Nomor 6 Tahun 1983 tentang Ketentuan Umum dan Tata Cara Perpajakan, selanjutnya dalam penelitian ini disebut UU KUP. 
Sedangkan menurut kami penting untuk melakukan kritik atas sesuatu meskipun telah mapan dan diikuti banyak orang. Meskipun telah ada beberapa upaya dari beberapa pihak untuk mendekonstruksi definisi pajak hingga menghasilkan wacana definisi pajak baru, namun hasil dekonstruksi dinilai belum menghasilkan suatu konsep yang bebas dari modernitas dengan pengarusutamaan materialisme sebagai satu cirinya.

Belum ada penelitian yang mengungkap atau menggali bahwa definisi pajak akan berimplikasi terhadap penyusunan sistem dan kebijakan perpajakan, yang bermuara kepada praktik perpajakan baik oleh DJP maupun oleh WP. Penelitian sebelumnya lebih menekankan kepada penggalian kenapa WP tidak mau membayar pajak, hal ini hanya merupakan hilir dari suatu proses penelitian. Penelitian ini mencoba untuk menggali akar permasalahan tersebut, dengan menarik ke atas dari tataran praktik, kemudian menuju tataran konsep, selanjutnya ke arah tataran pemikiran dan berlabuh pada tataran filosofi dalam penyusunan sistem dan kebijakan perpajakan di Indonesia.

Asumsi yang perlu dipahami dalam artikel ini bahwa fitrah manusia adalah taat pada Tuhan (divine consciousness). Bahwa sudah menjadi fitrah manusia untuk menaati aturan agama. Religiusitas seseorang akan terlihat dari perilaku sosialnya (Brañas-garza, Espín, dan Neuman 2013). Hal ini dapat direfleksikan dalam kepatuhan WP dalam memenuhi kewajiban perpajakan (Torgler 2003). Bahkan religiusitas juga akan nampak dalam praktik profesional konsultan pajak yang akan mampu meningkatkan kepatuhan pajak kliennya (Darmayasa dan Aneswari 2015).

Mengacu pada beberapa penelitian yang menggunakan perspektif nilai kearifan lokal Hindu mengenai perpajakan seperti yang dilakukan oleh Budiasih (2014) dan Widiastuti, Sukoharsono, Irianto, dan Baridwan (2015). Maka artikel ini akan mengambil salah satu value dalam kearifan lokal Hindu-Bali yang menjadi budaya sekaligus religiusitas bagi penganutnya. Sebuah budaya dan agama merupakan hal yang tak nampak, namun wujud dari nilai yang terkandung dalam budaya dan agama dapat dirasakan melalui manifestasi tindakan pemilik atau penganut budaya dan agama tersebut.

Kami menyadari bahwa diskusi perpajakan dikaitkan dengan keyakinan seseorang merupakan hal yang berat. Sebab religiusitas akan berkaitan dengan kepercayaan. Namun penting untuk dipahami sebelumnya bahwa diskusi ini akan mengacu dan mengarah pada nilai Hindu yang diarahkan pada konteks perpajakan Nasional. Beberapa penelitian perpajakan yang menggunakan nilai lokal Hindu-Bali belum ada yang menggali mengenai ketidakadilan yang tertuang dari definisi pajak. Sehingga dengan menggunakan nilai lokal Hindu-Bali Catur Purusa Artha sebagai lensa untuk membaca sebuah teks, dalam hal ini definisi pajak berdasarkan UU. Maka artikel ini bertujuan untuk mendekonstruksi definisi pajak tersebut.

\section{METODE PENELITIAN}

Paradigma dari suatu penelitian merupakan hal yang penting, sebab paradigma adalah penunjuk arah bagaimana sebaiknya peneliti memperoleh kebenaran dan ilmu 
pengetahuan melalui penelitiannya. Sesuai dengan pandangan Triyuwono (2006) bahwa paradigma dalam penelitian adalah cara pandang mengenai dunia atau worldview. Sebagai cara pandang, maka paradigma ini berjalan secara inline dengan apa yang menjadi keyakinan peneliti. Tanpa melepas konsep bahwa paradigma harus sesuai dengan apa yang diteliti, artinya disesuaikan dengan ontologi serta epistemologi penelitiannya.

Paradigma postmodern merupakan paradigma yang tidak setuju dengan modernitas. Ciri utama postmodern yang merupakan logosentrisme, dalam hal ini ditunjukkan dalam definisi pajak berdasarkan UU KUP yang dinilai sarat dengan nilai modernitas yakni semangat materialisme yang tinggi dan tidak menunjukkan keadilan atau bersifat pemaksaan. Gerakan postmodern dinilai mengadopsi banyak pemikiran atau cara pandang seperti interpretif atau kritis dengan segala cabang pemikirannya. Sehingga postmodern dinilai tidak memiliki bentuk yang jelas, namun ketidakjelasan bentuknya inilah merupakan bentuk asli postmodern (Triyuwono 2011).

Terdapat banyak budaya Bali yang bisa digunakan sebagai alat analisis sebuah penelitian sebagaimana dijelaskan dalam artikel Kamayanti (2015). Filosofi Hindu-Bali yang kami gunakan dalam penulisan artikel ini yakni Catur Purusa Artha (CPA). CPA kami gunakan dalam penulisan artikel ini dengan keyakinan bahwa CPA adalah lensa yang tepat untuk mendekonstruksi definisi pajak saat ini yang tidak berkeadilan. CPA merupakan empat tujuan hidup umat Hindu. Melalui empat prinsip yang terkandung dalam CPA yakni Dharma ${ }^{5}$, Artha ${ }^{6}$ dan $\mathrm{Kama}^{7}$ umat Hindu mencapai tujuan hidupnya yaitu $\mathrm{Moksa}^{8}$, selanjutnya filosofi CPA ini kami hubungkan ke dalam ranah perpajakan.

Kami memahami bahwa pajak merupakan salah satu mekanisme pemerintahan paling utama yang digunakan untuk mensejahterakan masyarakat. Definisi pajak saat ini kami nilai sarat dengan unsur materialitas dan meniadakan Tuhan. Hal ini merupakan cerminan modernitas yang memarjinalkan nilai-nilai lokal dengan mengarusutamakan materi dan meniadakan keberadaan Tuhan (Djamhuri 2011; Mulawarman 2006).

Bahkan definisi pajak berdasarkan UU KUP saat ini juga tidak menunjukkan keadilan sebagaimana yang telah menjadi asas dalam perpajakan. Ketidakadilan tercermin dari definisi pajak yang memberikan kewenangan kepada DJP untuk memungut pajak dengan cara memaksa dan ketidakadilan lainnya adalah WP tidak mendapatkan imbalan secara langsung. Definisi pajak yang tidak menyentuh hati WP bahkan terkesan tidak memihak pada mereka dengan menimbulkan asumsi ketidakadilan akan diabaikan oleh WP, sehingga definisi tersebut sebaiknya didekonstruksi.

Dharma adalah tujuan hidup umat Hindu yang pertama. Umat Hindu harus melaksanakan semua kegiatannya dengan landasan ajaran agama Hindu yakni kebenaran, kesetiaan, kejujuran, dan hukum.

Artha adalah tujuan hidup umat Hindu yang kedua. Artha merupakan harta benda, kekayaan, uang dan bendabenda lainnya. Artha yang dimaksud harus diperoleh dengan jalan Dharma. Artha yang diperoleh dimanfaatkan sesuai dengan jalan Dharma.

Kama adalah tujuan hidup umat Hindu yang ketiga. Kama adalah keinginan jasmani dan rohani

s Moksa merupakan tujuan hidup ke empat umat Hindu. Moksa merupakan tujuan yang paling tinggi, hakikat, dan mulia. Moksa atau kelepasan adalah kebebasan dari kelahiran kembali atau bersatunya Atman dengan Brahman (Tuhan). Dengan tercapainya Moksa, maka orang akan terbebas dari hukum karmapala, terbebas dari penjelmaan kembali secara berulang-ulang, terbebas dari punarbawa atau reinkarnasi 
Dekonstruksi merupakan cara memahami atau membaca teks untuk memberikan konsep baru pada teks yang telah dibaca. Dekonstruksi merupakan suatu metode yang menggabungkan sesuatu yang merupakan pusat (logosentris) dengan sesuatu lainnya sehingga menghasilkan yang baru. Dalam hal ini definisi pajak berdasarkan UU KUP adalah logosentrisnya. Sehingga dekonstruksi ibarat menggabungkan hidrogen dengan oksigen sehingga menjadi air (Triyuwono 2015).

Dekonstruksi definisi pajak dalam artikel ini dilakukan dengan lensa CPA melalui analisa berdasarkan konsep yang ada dalam CPA, yakni Dharma, Artha, Kama, dan Moksa. Definisi pajak berdasarkan UU KUP akan dinilai apakah telah sesuai dengan empat value CPA tersebut. Sehingga hasil dekonstruksi pajaknya adalah memasukkan empat value tersebut sebagai alat untuk memasukkan misi keadilan dalam definisi pajak yang baru dengan menghilangkan unsur pemaksaan dan menghilangkan konsep yang secara eksplisit menunjukkan pengarusutamaan material.

Artikel ini mencoba menyajikan hasil dekonstruksi sekaligus memberi wacana mengenai berbagai pendapat dari informan mengenai definisi pajak dari sudut pandang keadilan baik yang menunjukkan pro maupun kontra. Tujuannya adalah memberi keleluasaan bagi pembaca untuk setuju atau tidak dengan segala konsep pemikiran yang kami ajukan dalam artikel ini. Sehingga penelitian juga dilakukan melalui wawancara untuk menggali pemahaman serta pemikiran dari berbagai pihak.

Informan penelitian difokuskan kepada informan yang beragama Hindu yang terkait dengan praktik perpajakan. Informan penelitian berlatar belakang akademisi, konsultan pajak dan WP dengan pertimbangan pihak-pihak tersebut yang merasakan ketidakadilan dari definisi pajak. Penelitian ini tidak menyertakan informan dari DJP sebab ketidakadilan definisi pajak tidak dirasakan oleh DJP. Keadilan menurut perspektif DJP sangat berbeda dengan perspektif WP, konsultan pajak maupun akademisi. Informasi mengenai informan penelitian, keterkaitan informan dengan praktik perpajakan beserta waktu wawancara disajikan pada Tabel 1.

Tabel 1

Daftar Informan

\begin{tabular}{|c|l|l|l|}
\hline No & \multicolumn{1}{|c|}{$\begin{array}{c}\text { Subjek } \\
\text { Informan }\end{array}$} & \multicolumn{1}{|c|}{ Keterangan } & \multicolumn{1}{|c|}{ Waktu } \\
\hline 1 & $\begin{array}{l}\text { Bapak Made } \\
\text { Bagiada }\end{array}$ & $\begin{array}{l}\text { Wajib Pajak Orang } \\
\text { Pribadi (WPOP) }\end{array}$ & $\begin{array}{l}\text { Diskusi informal mengenai } \\
\text { perkembangan usaha untuk } \\
\text { menyambut tahun 2016, pada Kamis, } \\
\text { 31 Desember 2015 }\end{array}$ \\
\hline 2 & $\begin{array}{l}\text { Bapak Made } \\
\text { Arnaya }\end{array}$ & $\begin{array}{l}\text { Akuntan dan } \\
\text { Konsultan Pajak }\end{array}$ & $\begin{array}{l}\text { Diskusi informal pada saat membahas } \\
\text { perkembangan profesi akuntan dan } \\
\text { konsultan pajak pada Kamis, 14 } \\
\text { Januari 2016 }\end{array}$ \\
\hline 3 & $\begin{array}{l}\text { Bapak } \\
\text { Syoman }\end{array}$ & $\begin{array}{l}\text { Konsultan Pajak } \\
\text { yang } \\
\text { Kesehariannya } \\
\text { Sebagai pemimpin } \\
\text { upacara umat Hindu }\end{array}$ & $\begin{array}{l}\text { Corporate Tax Planning pada Selasa, } \\
\text { 2 Februari 2016 }\end{array}$ \\
\hline 4 & $\begin{array}{l}\text { Bapak Made } \\
\text { Sedana Yasa }\end{array}$ & $\begin{array}{l}\text { Akademisi (Dosen } \\
\text { Pengampu } \\
\text { Perpajakan) }\end{array}$ & $\begin{array}{l}\text { Diskusi informal pada Senin, 22 } \\
\text { Februari 2016 }\end{array}$ \\
\hline
\end{tabular}

Sumber: Tim Peneliti 
Pengumpulan data dan pengolahan data dalam penelitian ini dilakukan sepanjang proses penelitian. Data hasil wawancara selanjutnya disusun dalam tema-tema yang sesuai dengan empat tujuan hidup CPA yaitu: Dharma, Artha, Kama, dan Moksa. Tematema yang sudah disesuaikan dengan CPA bertujuan untuk memudahkan dekonstruksi definisi pajak yang tidak berkeadilan. Penyusunan tema-tema tidak bertujuan untuk membahas dekonstruksi definisi secara parsial namun sebaliknya mendekonstruksinya secara holistik. Definisi pajak sesuai dengan UU KUP yang mengandung ketidakadilan selanjutnya berdasarkan tema-tema yang telah disusun didekonstruksi pada bagian-bagian yang mengandung ketidakadilan. Proses dekonstruksi definisi pajak yang tidak berkeadilan dengan memasukkan nilai-nilai Artha dan Kama yang berlandaskan Dharma untuk mewujudkan definisi pajak yang berkeadilan disajikan dalam Bagan 1.

\section{Bagan 1}

Dekonstruksi Definisi Pajak Yang Berkeadilan

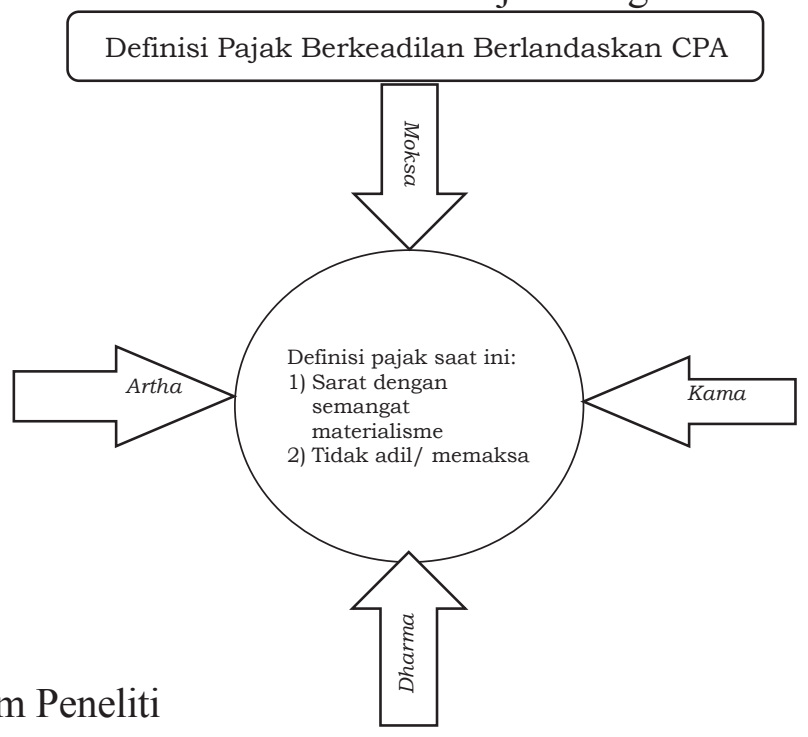

Sumber: Tim Peneliti

\section{HASIL DAN PEMBAHASAN}

Definisi Pajak yang Tidak Berkeadilan. Sebelum melakukan proses dekonstruksi definisi pajak, penting untuk menyisir sisi ketidakadilan definisi pajak yang telah diterapkan selama ini. Perlu dilakukan upaya untuk mendekonstruksi definisi pajak tersebut. Meskipun definisi pajak tersebut telah mapan dan disepakati oleh banyak pihak bahkan telah dilegitimiasi dalam UU KUP. Sebagaimana telah dijelaskan sebelumnya bahwa upaya untuk melakukan dekonstruksi pajak ini telah dilakukan melalui sebuah kongres pajak sedunia yang mengusulkan beberapa wacana definisi pajak yang baru yang mengarahkan pada semangat keadilan dan membangun kepatuhan pajak.(Rosdiana dan Irianto 2014:2).

Menjadi suatu pertanyaan besar kenapa definisi pajak yang terdapat dalam UU KUP mengandung ketidakadilan bagi WP. Padahal keadilan merupakan asas dalam pemungutan pajak, seperti yang diungkapkan oleh Rosdiana dan Irianto (2014:161162) bahwa pemungutan pajak dikatakan adil jika memenuhi keadilan horizontal dan vertikal. Hal senada juga diungkapkan oleh Plasschaert (1988:105) bahwa sistem pajak dikatakan berhasil jika WP merasa yakin terhadap pajak yang dipungut 
pemerintah yang dikenakan secara adil. Keadilan horizontal terjadi apabila WP yang berada dalam kondisi yang sama diperlakukan sama (equal treatment for the equals). Sedangkan keadilan vertikal terpenuhi apabila WP yang mempunyai tambahan kemampuan ekonomis yang berbeda diperlakukan tidak sama (Rosdiana dan Irianto 2014:161-163).

Beberapa ahli juga mengajukan pendapat definisi pajak, namun pada konsep tersebut masih melekat semangat materialisme dan ketidakadilan di dalamnya. Pandangan yang diungkapkan oleh Soemitro dan Sugiharti (2010:31) bahwa pajak merupakan pungutan atau peralihan kekayaan dari rakyat kepada penguasa tanpa ada imbalannya yang secara langsung dapat ditunjuk. Pajak mengurangi penghasilan individu yang tidak ada imbalannya, sehingga mengurangi harta WP, dan dengan sendirinya mengurangi daya belinya. Jika daya beli berkurang, maka hal ini berarti mengurangi kemampuan untuk memenuhi kebutuhannya.

Terdapat pendapat berbeda dari informan kami mengenai sudut pandang keadilan definisi pajak berkaitan dengan tidak adanya imbalan langsung dari pajak yang telah dipotong. Pendapat Bapak Sedana Yasa menyatakan sebagai berikut:

"Ya, karena imbalan yang diberikan oleh pemerintah untuk kepentingan seluruh masyarakat"

Meskipun dalam definisi pajak tertera jelas bahwa WP tidak akan mendapatkan imbalan secara langsung, namun mekanisme ini tetaplah adil menurut Bapak Sedana Yasa. Sebab konsep "imbalan" menurut bapak Sedana Yasa merupakan bentuk distribusi yang merata bagi kepentingan banyak pihak.

Bapak Made Arnaya terlihat berpikir sejenak dalam memberikan tanggapannya perihal tidak adanya imbalan secara langsung. Menurut Bapak Made Arnaya memang WP tidak mendapat imbalan secara langsung dari pajak yang dibayarkannya. Namun fasilitas yang dirasakan saat ini merupakan hasil dari pembayaran pajak. Pernyataan Bapak Made Arnaya mengenai tidak adanya imbal balik secara langsung tersebut tidak serta merta mengatakan bahwa hal tersebut adalah termasuk sisi ketidakadilan.

Berbeda dengan tanggapan Bapak Made Bagiada yang merupakan WPOP, pernyataan Bapak Made Bagiada adalah:

"Memang definisinya menyatakan tidak mendapatkan imbalan secara langsung, namun pemerintah jika mampu memberikan imbalan kepada WP yang patuh membayar pajak akan terasa lebih adil bagi WP tersebut. Saya sebagai WPOP akan lebih merasakan keadilan jika ada manfaat langsungnya, tidak harus materi mungkin dalam bentuk lain, pemerintah lebih pinter lah mengaturnya"

Pendapat ini mengarah pada pendapat bahwa sebaiknya WP mendapatkan imbalan yang secara langsung yang dapat dirasakan. Imbalannya bukan harus berupa materi, namun bisa berupa suatu manfaat yang dapat dirasakan oleh WP.

Definisi pajak saat ini apabila ditinjau dari segi individu (mikro ekonomi) memang tidak dirasakan imbal balik langsungnya. Tetapi apabila soal pajak ditinjau dari segi kemasyarakatan (makro ekonomi), maka tidak dapat dikatakan bahwa pajak itu sama sekali tidak ada imbalannya. Ada imbalan secara tidak langsung bagi individu yang hidup dalam masyarakat, seperti yang terlihat dalam infrastruktur, keamanan, kesejahteraan, kesehatan, pendidikan, dan sebagainya. Menurut kami, pandangan ini tidak seluruhnya tepat mengingat dalam definisi pajak terkandung makna-makna tersembunyi yang dipandang oleh WP sebagai suatu ketidakadilan. 
Makna keadilan menurut masyarakat Indonesia berbeda dengan masyarakat barat. Masyarakat Indonesia mendefinisikan adil sebagai sesuatu yang ada pada tempatnya, dekat dengan ketakwaan (vertikal), dan memberikan kepuasan (horizontal) (Alim 2015).

Ketidakadilan definisi pajak yang memberikan kewenangan kepada DJP untuk memungut pajak yang bersifat memaksa, kami yakini merupakan sumber dari praktik perpajakan yang tidak sehat. Praktik yang tidak sehat bisa terwujud dalam bentuk kekuasaan pegawai DJP dalam hal melakukan pemeriksaan pajak. Pemeriksa pajak dengan tujuan lain ${ }^{9}$ berhak mengumpulkan data WP. Tujuan lain dalam pemeriksaan tersebut cenderung digunakan untuk memenuhi target masing-masing individu pemeriksa pajak yang secara agregat merupakan pemenuhan target DJP. Pemeriksa pajak secara legal melakukan pencarian-pencarian demi kepentingan negara dibawah perlindungan undang undang. Makna tujuan lain yang terdapat dalam definisi pemeriksaan bisa digunakan secara bias oleh pemeriksa pajak.

Namun pendapat informan kami menyatakan bahwa mekanisme pemaksaan dalam pajak yang secara eksplisit tercantum dalam definisi pajak masih masuk dalam koridor keadilan. Kutipan wawancara dengan Bapak Sedana Yasa sebagaimana tercantum berikut:

“...karena memaksa yang dimaksud dalam peraturan justru untuk menerapkan keadilan kepada wajib pajak"

Pendapat yang mendukung pernyataan Bapak Sedana Yasa diajukan oleh informan Bapak Sugianta sebagai berikut:

“...karena tanpa dipaksa WP tidak akan patuh membayar pajak."

Berdasarkan penyataan Bapak Sedana Yasa dapat dipahami bahwa mekanisme "pemaksaan" dalam definisi pajak merupakan penerapan keadilannya. Didukung oleh pendapat Bapak Sugianta bahwa pemaksaan dilakukan dengan tujuan untuk meningkatkan kepatuhan pajak WP. Melanjutkan penjelasan informan Bapak Sedana Yasa bahwa mekanisme pemaksaan ini ditujukan bagi WP yang melakukan tax evasion yang secara legalitas tidak diperkenankan. Sehingga harus diterapkan pemaksaan agar WP yang memiliki evasion minded agar mau mematuhi regulasi perpajakan.

Sebaliknya argumentasi informan kami bapak Sedana Yasa dan Bapak Sugianta di atas berlawanan dengan artikel Triyuwono (2009). Tujuan utama pemeriksaan pajak adalah untuk menguji kepatuhan pemenuhan kewajiban perpajakan WP. Bukankah hal ini bertentangan dengan sistem perpajakan di Indonesia, yang mana semenjak reformasi tahun 1983 sistem perpajakan Indonesia adalah Self Assessment System (SAS) (Bawazier 2011; Setiyaji dan Amir 2005). Terjadi dialektika antara DJP dengan WP. SAS memberikan kepercayaan, namun upaya pemeriksaan menguji kepercayaan tersebut atau dengan kata lain tidak percaya terhadap WP (Triyuwono 2009).

Melalui SAS peran WP lebih aktif dari pada pegawai DJP. Pada implementasi SAS WP diberi kewenangan untuk menghitung, memperhitungkan, menyetor, dan melaporkan kewajiban perpajakannya sendiri (Ilyas dan Burton 2012; Okello 2014).

\footnotetext{
9 Definisi Pemeriksaan sesuai dengan UU No. 28 Tahun 2007 tentang Ketentuan Umum dan Tata Cara Perpajakan pasal 1 (25), pemeriksaan adalah serangkaian kegiatan menghimpun dan mengolah data, keterangan, dan/atau bukti yang dilaksanakan secara objektif dan profesional berdasarkan suatu standar pemeriksaan untuk menguji kepatuhan pemenuhan kewajiban perpajakan dan/atau untuk tujuan lain dalam rangka melaksanakan ketentuan peraturan perundang-undangan perpajakan.
} 
Memang menjadi suatu lingkaran tanpa ujung, apakah SAS akan meningkatkan kepatuhan pajak ataukah kepatuhan pajak akan meningkat seiring dengan implementasi SAS (Darmayasa dan Aneswari 2015). Namun yang kami pahami bahwa pelaksanaan pemeriksaan oleh DJP mengindikasikan bahwa DJP belum percaya dengan WP.

Pandangan lainnya mengenai kata pemaksaan yang tertera eksplisit pada definisi pajak muncul dari informan Bapak Made Arnaya dan Bapak Made Bagiada. Bapak Made Arnaya menyatakan:

"Bisa jadi DJP menggunakan kata memaksa untuk memungut pajak dengan cara sedikit memaksa karena memang target penerimaan pajak relatif tinggi, belakangan ini banyak sekali ada klien saya yang mendapatkan himbauan pembetulan SPT atau malah langsung pemeriksaan"

Pandangan yang sejalan disampaikan oleh Bapak Made Bagiada:

"Bayar pajak bagi saya memang sangat berat terasa, kalau ndak dipaksa mungkin tidak ada yang mau bayar pajak, tapi harusnya jangan dipaksa terus, seyogyanya DJP mampu menumbuhkan kepatuhan WP sendiri"

Target penerimaan pajak selalu meningkat dari tahun ke tahun. Sedangkan kepatuhan WP di Indonesia amatlah rendah. Sehingga tidak dapat dipungkiri beban DJP semakin berat. Maka diperlukan berbagai tax effort untuk mengejar target tersebut, yakni melalui pemaksaan yang dilakukan dengan berbagai mekanisme mulai dari himbauan pembetulan SPT maupun pemeriksaan. "Pemaksaan" yang dilakukan DJP terhadap WP sudah terlegalisasi dengan tertera secara jelas di dalam definisi pajak berdasar UU.

Catur Purusa Artha (CPA): Lensa Dekonstruksi. Beberapa penelitian telah dilakukan untuk mengaitkan antara pajak dengan tataran religiusitas. Salah satu penelitian yang berupaya merekonstruksi sistem perpajakan yang berlaku pada saat ini dilakukan oleh Triyuwono (2009) dengan merekonstruksi SAS menjadi free self assessment and payment system. Usulan tersebut masih terbatas pada subjek pajak orang pribadi, bukan untuk keseluruhan ${ }^{10}$ subjek pajak. Penelitian yang mencoba mengaitkan antara pajak dan zakat dilakukan oleh Kholifah (2013) dan Tolkah (2012). Hasil penelitian Kholifah (2013) mengusulkan pajak merupakan badan atau lembaga, sedangkan jiwa kepatuhannya adalah zakat, sehingga pajak dan zakat merupakan satu kesatuan. Berbeda dengan Tolkah (2012) yang mengusulkan bahwa zakat bisa digunakan sebagai pengurang dalam perhitungan penghasilan kena pajak (PhKP) WP. Namun secara garis besar kesamaan dari penelitian keduanya bahwa zakat merupakan satu mekanisme yang mampu meningkatkan kepatuhan pajak, karena pemicu pelaksanaannya adalah sisi religiusitas yang dimanifestasikan dalam keikhlasan dari dalam hati WP.

Manifestasi religiusitas yang merupakan tujuan hidup WP yang akan digunakan sebagai lensa dekonstruksi definisi pajak terdiri dari: 1) Dharma, 2) Artha, 3) Kama dan 4) Moksa. Empat visi hidup berdasarkan Purusa Artha tidak boleh dimaknai sendiri-sendiri secara terpisah bagian per bagian. Sebab secara bagian akan benar, namun secara keseluruhan akan menjadi keliru bahkan menyimpang.

Sebagaimana asumsi yang menjadi benang merah artikel ini, bahwa fitrah manusia adalah mencari ketentraman dengan kembali pada Tuhan Yang Maha Esa

10 Menurut UU No. 36 Tahun 2008 Tentang Pajak Penghasilan, pada pasal 2 ayat 1, Subjek Pajak terdiri dari: 1) orang pribadi, 2) warisan yang belum terbagi sebagai satu kesatuan menggantikan yang berhak, 3) badan, dan 4) bentuk usaha tetap (BUT) 
dengan mematuhi semua aturan Tuhan. Atau dalam konsep CPA adalah Moksa (menyatu dengan Tuhan). Nilai-nilai kearifan lokal yang selalu dipegang teguh oleh WP harusnya dijadikan suatu tuntunan sehingga hati WP mampu tergerak untuk sadar dan taat membayar pajak. Nilai-nilai lokal selama ini termarjinalkan oleh nilainilai yang menjunjung kapitalisme, bahkan mendewakan materi dengan mengesampingkan keberadaan Tuhan. Untuk memasukkan nilai-nilai lokal yang akan digunakan untuk mendekonstruksi definisi pajak.

Hasil wawancara dengan berbagai informan akan disusun ke dalam tema-tema yang disesuaikan dengan konsep CPA. Hasil penelusuran berbagai literatur yang terkait dengan topik penelitian digunakan untuk membantu proses dekonstruksi definisi pajak yang tidak berkeadilan. Pandangan para informan penelitian akan disusun ke dalam Dharma, Artha, Kama, dan Moksa. Susunan pandangan informan disajikan secara berurutan sesuai dengan filosofi konsep CPA yang diawali dari Dharma, Artha, Kama, dan Moksa.

Dharma merupakan tujuan hidup pertama dalam konsep CPA. Dharma dimaknai sebagai ibadah dalam bentuk lebih luas dalam artikel ini. Yakni segala perbuatan manusia yang mengacu pada hal-hal yang diperintah oleh Tuhan Maha Besar. Terutama perbuatan manusia berkaitan dengan kewajibannya sebagai warga negara. Manusia dalam penelitian ini merujuk pada WP. Penjelasan mengenai konsep Dharma tercantum dalam Kitab Sarasamuccaya dalam sloka 8 dan sloka 12 sebagai berikut.

Sloka 8:

Manusyam durlabham

prapya widyullassitacandalam

bhawaksaye matih karya

bhawopakarensu ca

Artinya:

Menjadi manusia itu hanya sebentar

Tidak berbeda dengan kilatnya petir

Gunakan melakukan dharma sadhana

Memusnahkan derita dan sorga pahalanya

Sloka 12:

Karmarthau lipsamanastu

dharmmam ewaditascaret

na hi dharmmadapetyarthah

kamo wapi kadacana

Artinya:

Jika artha dan kama yang akan dicari

Lakukan ajaran dharma terlebih dahulu

Artha dan kama pasti akan diperoleh

Kecuali jika menyimpang dari kebenaran

Makna kedua sloka di atas adalah kehidupan yang hanya sebentar sebaiknya dijalani dengan penuh dharma. Ketika hidup telah diniatkan untuk ibadah atau pengabdian pada Tuhan, maka rejeki berupa artha (materi) dan kama (kesejahteraan lahir dan batin) pasti akan tercapai pula. Dalam hal ini ada banyak cara manusia sebagai WP untuk melakukan dharma yang selaras dengan kewajibannya sebagai warga negara. 
Dharma atau pengabdian yang bisa dilakukan oleh WP sebagai warga negara salah satunya melalui ketaatannya pada regulasi perpajakan secara ikhlas. Sebaliknya DJP sebagai otoritas juga harus melakukan dharma serupa. Dharma yang dapat dilakukan oleh DJP antara lain dengan memformulasikan regulasi perpajakan yang adil serta membenahi kualitas institusi agar tidak ada lagi oknum otoritas perpajakan yang melakukan moral hazard.

Artha merupakan harta benda yang bersifat materiil yang merupakan tujuan hidup kedua berdasarkan CPA. Dalam hal ini artha merupakan sarana bagi WP untuk melakukan dharma kepada negara. Menekankan dharma yang dilakukan oleh WP berupa pembayaran pajak yang berasal dari artha miliknya.

Dijelaskan dalam rgveda $V .76 .5$

$A$ visvani amrta saubhagani

Artinya:

Ya Tuhan, limpahkanlah kepada kami kekayaan yang suci atau bersifat kedewataan.

Dalam rgveda X.117.5

Prnyad id nadhamanaya tavyan

draghiyamsam anu pasyeta pantham

o hi vartante rathyeva cakra

anyam anyam up tisthanta rayah

Artinya:

Bermurah hatilah untuk memberi sesuatu sebagai dana punia kepada orang miskin. Kekayaan itu berputar bagaikan roda, demikian pula Artha atau kekayaan itu bergulir dari seseorang kepada orang lain.

Umat Hindu sebagaimana umat Islam memiliki ajaran serupa dalam hal bagaimana harta diperoleh dan mekanisme mengenai membagikan harta pada pihak lain. Artha atau harta harus diperoleh melalui jalan dharma dan harus disedekahkan sebagai bentuk dharma pula. Istilah sedekah pada harta ini disebut sebagai dana punia dalam Hindu atau zakat dalam Islam.

Mekanisme dana punia atau zakat ini kemudian dibuat suatu pengandaian oleh Triyuwono (2009) melalui Metafora Zakat (MZ) dalam pemungutan pajak. Sehingga pajak merupakan bagian dari dharma WP dengan mengasumsikan pajak yang dikeluarkan diniatkan sebagai dana punia atau zakat. Sehingga ketika pembayaran pajak dilakukan, kewajiban sebagai warga negara terpenuhi sekaligus melaksanakan perintah Tuhan. Hal ini sebagaimana disampaikan oleh Kholifah (2013) bahwa pajak adalah lembaganya, zakat adalah jiwanya.

Analogi zakat ini dirumuskan secara lebih terperinci yang dimasukkan sebagai pengembangan kebijakan fiskal oleh Alim (2013 : 69). Sehingga organisasi pengelola zakat harus memiliki sistem yang terintegrasi dengan DJP. Setiap kali zakat yang dibayarkan oleh WP, akan otomatis mengurangkan kewajiban pajaknya sebagai bentuk kompensasi (Alim 2013 : 51-52). Jumlah pembayaran zakat di Indonesia tidak boleh dipandang sebelah mata sebab tren penerimaan zakat setiap tahunnya terus mengalami kenaikan 15-35\% (Firatmaja 2015). Data penerimaan zakat bulan September tahun 2015 menunjukkan nominal yang cukup besar yakni Rp 78.7 Triliun (Republik Indonesia 2016).

Kama merupakan tujuan hidup yang ketiga dalam CPA yakni hawa nafsu atau keinginan. Dalam artikel ini makna Kama merujuk pada keinginan atau kebutuhan 
jasmani maupun rohani. Kontribusi artha yang dilakukan oleh WP melalui pembayaran pajak akan menjadi sumber penerimaan negara untuk belanja kebutuhan publik. Kebutuhan publik ini ditujukan untuk kemakmuran rakyat. Dalam hal ini kemakmuran yang wajib dipenuhi oleh pemerintah selaku otoritas adalah kemakmuran berupa kemakmuran jasmani maupun rohani (kama).

Bapak Arnaya menyampaikan pendapatnya mengenai visi hidup berdasarkan CPA dikaitkan dengan definisi pajak sebagai berikut:

“...harusnya DJP menggunakan ajaran Dharma dengan menyediakan sarana prasarana terlebih dahulu, selanjutnya biarkan iklim ekonomi tumbuh baru pungut pajak, setelah pajak terpungut maka distribusikan dengan niat baik (kama) dari DJP untuk kemakmuran rakyat"

Pendapat tersebut melihat konsep pajak dari sudut pandang up to bottom. Bahwa definisi pajak yang dikaitkan dengan konsep kepatuhan pajak diawali melalui segala fasilitas mendukung yang disediakan pemerintah yang diasumsikan sebagai wujud dharma pemerintah. Fasilitas dan sarana yang disediakan akan merangsang pertumbuhan ekonomi, sehingga kemampuan ekonomis warga negara sebagai WP juga akan meningkat, sehingga bisa dipajaki. Dari penerimaan pajak yang terkumpul, pemerintah memiliki kewajiban untuk mendistribusikan dengan niat baik secara merata dan adil. Niat baik dalam hal ini oleh informan diyakini sebagai bentuk kama.

Telah dijelaskan sebelumnya dalam Kitab Sarasamuccaya sloka 12 bahwa untuk meraih Kama atau Artha maka harus melaksanakan Dharma terlebih dahulu. Makna sloka ini dapat dihubungkan dengan konsep perpajakan nasional dengan menggunakan Metafora Zakat (MZ). Menekankan pada pencapaian Kama sesuai dengan subbab ini, maka WP melakukan pembayaran pajak sebagai bentuk dharma dengan melakukan analogi zakat atau dana punia dalam Hindu, atas pajak yang dibayarkan. Melalui pembayaran pajak tersebut, maka pemerintah akan memiliki penerimaan untuk melakukan pembelanjaan untuk kepentingan masyarakat secara keseluruhan.

Moksa ini selaras dengan asumsi utama artikel ini mengenai fitrah manusia untuk taat kepada Tuhan. Hindu memiliki paham mengenai Monisme, yakni paham yang memandang segala realitas adalah tunggal. Tuhan adalah tunggal, Maha Esa. Tuhan adalah sumber dan satu kesatuan dengan makhluknya. Semua yang ada di jagat raya ini adalah satu kesatuan. Rasa satu kesatuan antara manusia dengan sesama (Tat Twam Asi), dengan alam dan dengan Tuhan. Konsep kesatuan ini adalah advaita, yakni monisme meyakini bahwa seluruh jagat raya dipandang sebagai emanasi (mengalir) dari Tuhan (Mardiono 2016).

Dalam Kitab Weda dijelaskan :

Moksartham jagadhita ya ca iti dharma

Artinya:

Tujuan agama atau dharma adalah untuk mencapai jagadhita dan moksa

Moksa jika dihubungkan dengan perpajakan yakni semua dharma yang dilakukan oleh WP melalui kontribusi artha dilakukan dengan tujuan moksa. Yakni atas dasar ikhlas karena tujuan utamanya adalah untuk mendapatkan berkah dari Yang di Atas.

Dekonstruksi Definisi Pajak Berdasarkan CPA. Pendapat pro maupun kontra dari informan-informan yang kami wawancara menghasilkan wacana yang memperkaya artikel ini. Berbagai pendapat, literatur, konsep CPA dan pemikiran kami disatukan untuk menghasilkan sebuah dekonstruksi definisi pajak. Sehingga 
berdasarkan pembahasan empat prinsip hidup CPA yang kami kaitkan dengan perpajakan di atas menghasilkan sebuah dekonstruksi definisi baru pajak yaitu : Pajak adalah Dharma dalam bentuk kontribusi uang yang dilakukan secara tulus ikhlas yang berasal dari Artha orang pribadi atau badan kepada negara yang didistribusikan bagi sebesar-besar kemakmuran rakyat berlandaskan Kama.

Beberapa makna yang ingin kami sampaikan dari dekonstruksi definisi pajak yang diajukan tersebut bahwa 1) pajak merupakan pengabdian yang bentuknya adalah kontribusi artha dari orang pribadi atau badan pada negara, 2) kontribusi tersebut diatur dalam Undang-undang bagi keperluan negara untuk belanja publik bagi kemakmuran rakyat. 3) Yang mana kemakmuran rakyat dalam hal ini yang wajib dipenuhi negara adalah kemakmuran kama, yakni kemakmuran berupa jasmani maupun rohani.

\section{SIMPULAN DAN SARAN}

Definisi pajak berdasarkan UU KUP saat ini dinilai sarat dengan modernitas. Semangat modernitas yang ditunjukkan dalam definisi tersebut nampak dalam pengarusutamaan materialitas, pendikotomian Tuhan atau agama serta menunjukkan ketidakadilan bagi WP. Definisi pajak merupakan hal penting sebab akan menunjukkan sifat, tujuan, dasar dan mekanisme pemungutan pajak. Berawal dari definisi pajak yang akan dimaknai oleh WP maka akan mampu mempengaruhi keputusan tindakan WP apakah akan taat pada regulasi perpajakan atau sebaliknya.

Beberapa gerakan telah dilakukan sebagai upaya untuk melakukan dekonstruksi definisi pajak. Namun kami menilai wacana definisi baru yang muncul masih sarat dengan materialitas. Sehingga perlu mengajukan sebuah definisi pajak yang mampu menunjukkan keadilan serta akan dapat mendorong kepatuhan pajak.

Menggunakan salah satu konsep Hindu-Bali yakni CPA sebagai lensa dekonstruksi. Definisi pajak yang diajukan menggunakan fitrah manusia untuk taat pada Tuhan sebagai bentuk divine consciousness atau kesadaran Ilahi sebagai landasan. Empat konsep dalam CPA yakni dharma, artha, kama dan moksa kemudian dijadikan sebagai lensa untuk memahami definisi pajak saat ini yang menghasilkan definisi pajak yang baru. Sehingga berdasarkan lensa tersebut definisi pajak yang diajukan adalah Pajak adalah Dharma dalam bentuk kontribusi uang yang dilakukan secara tulus ikhlas yang berasal dari Artha orang pribadi atau badan kepada negara yang didistribusikan bagi sebesar-besar kemakmuran rakyat berlandaskan Kama.

Konsep religiusitas yang kami bawa sebagai lensa dekonstruksi definisi pajak menekankan pada Manunggaling kawulo Gusti (Triyuwono 2009). Kedudukan kawulo dalam konteks religiusitas membutuhkan adanya sikap yang bernama kepatuhan dan keikhlasan (Suyatno 2016). Sehingga hasil dekonstruksi ini menekankan pada "tulus ikhlas" yang dalam konsep perpajakan mengarah pada kepatuhan pajak sukarela (voluntary tax compliance).

Beberapa makna yang muncul dari dekonstruksi definisi pajak yang diajukan tersebut adalah 1) pajak merupakan pengabdian yang bentuknya adalah kontribusi artha dari orang pribadi atau badan pada negara, 2) kontribusi tersebut diatur dalam undang-undang bagi keperluan negara untuk belanja publik bagi kemakmuran rakyat. 3) Yang mana kemakmuran rakyat dalam hal ini yang wajib dipenuhi negara adalah kemakmuran kama, yakni kemakmuran berupa jasmani maupun rohani. 


\section{DAFTAR REFERENSI}

Alim, Mohammad Nizarul. 2013. Analogi Fiskal Syariah Di Indonesia Perspektif Zakat. Madura: UTM Press Universitas Trunojoyo Madura.

Alim, Mohammad Nizarul. 2015. "Pajak Dan Prinsip Keadilan." Madura: Disampaikan dalam Simposium Nasional Perpajakan (SNP) 5, Universitas Trunojoyo Madura 12 November 2015.

Aneswari, Yuyung Rizka, I. Nyoman Darmayasa, dan Elana Era Yusdita. 2015. "Perspektif Kritis Penerapan Pajak Penghasilan 1\% Pada UMKM." in Simposium Nasional Perpajakan 5 Fakultas Ekonomi - Universitas Trunojoyo Madura, 12 November 2015. Madura: Universitas Trunojoyo, 12 Nopember 2015.

Bawazier, Fuad. 2011. "Reformasi Pajak Di Indonesia." Jurnal Legesi Indonesia $8(1): 1-12$.

Brañas-garza, Pablo, Antonio M. Espín, and Shoshana Neuman. 2013. "Effects of Religiosity on Social Behaviour : Experimental Evidence from a Representative Sample of Spaniards." IZA Discussion Paper (7683).

Budiasih, I. Gusti Ayu Nyoman. 2014. "Fenomena Akuntabilitas Perpajakan Pada Jaman Bali Kuno: Suatu Studi Interpretif." Jurnal Akuntansi Multiparadigma 5(3):409-20.

Darmayasa, I. Nyoman dan Yuyung Rizka Aneswari. 2015. "The Ethical Practice of Tax Consultant Based on Local Culture." Procedia - Social and Behavioral Sciences 211(September):142-48.

Djamhuri, Ali. 2011. "Ilmu Pengetahuan Sosial Dan Berbagai Paradigma Dalam Kajian Akuntansi." Jurnal Akuntansi Multiparadigma 2 No 1(April):147-85.

Firatmaja, Fian. 2015. "Setiap Tahun Penerimaan Zakat Baznas Meningkat." Republika. Retrieved March 1, 2016 (http://republika.co.id).

Ilyas, Wirawan B. dan Richard Burton. 2012. Manajemen Sengketa Dalam Pungutan Pajak: Analisis Yuridis Terhadap Teori Dan Kasus. Jakarta: Penerbit Mitra Wacana Media.

Kamayanti, Ari. 2015. "Sain' Memasak Akuntansi: Pemikiran Udayana Dan Tri Hita Karana." Jurnal Riset dan Aplikasi: Akuntansi dan Manajemen 1(2):7380 .

Kholifah, Dewi. 2013. "Studi Komparatif Antara Pemikiran Fazlur Rahman Dan Masdar Farid Mas'udi Tentang Pajak Dan Zakat." Institut Agama Islam Negeri Walisongo, Semarang.

Mardiasmo. 2013. Perpajakan Edisi Revisi. Yogyakarta: Penerbit Andi. 
Mardiono, Bambang In. 2016. "Pandangan Keagamaan Bung Karno Untuk Persatuan Bangsa Dan Perdamaian Dunia Yang Abadi." in Diskusi Pembaca Aktif di Perpustakaan Bung Karno 02 Maret 2016 dengan Tema Religiusitas Soekarno. Blitar: UPT Perpustakaan Proklamator Bung Karno.

Mulawarman, Aji Dedi. 2006. Menyibak Akuntansi Syari'ah: Rekonstruksi Teknologi Akuntansi Syari'ah Dari Wacana Keaksi. Yogyakarta: Kreasi Wacana.

Okello, Andrew. 2014. "Managing Income Tax Compliance through.” IMF Working Paper 41(March):4-32.

Plasschaert, Sylvain R. F. 1988. "Schedular, Global and Dualistic Patterns of Income Taxation."

Republik Indonesia. 2016. BADAN AMIL ZAKAT NASIONAL PENERIMAAN DAN PENYALURAN TAHUN 2015 BULAN SEPTEMBER 2015. Retrieved (http://pusat.baznas.go.id).

Rosdiana, Haula dan Edi Slamet Irianto. 2014. Pengantar Ilmu Pajak Kebijakan Dan Implementasi Di Indonesia. Jakarta: PT Raja Grafindo Persada.

Setiyaji, Gunawan dan Hidayat Amir. 2005. "Evaluasi Kinerja Sistem Perpajakan Indonesia." Jurnal ekonomi 7(November):1-13.

Soemitro, Rochmat dan Dewi Karnia Sugiharti. 2004. Asas Dan Dasar Perpajakan. Bandung: Refika Aditama.

Suyatno. 2016. "Religiositas Sukarno: Sebuah Pengantar Diskusi Forum Kounitas Pembaca Aktif Koleksi Khusus Perpustakaan Proklamator Bung Karno, Perpustakaan Nasional RI." in Diskusi Pembaca Aktif Di Perpustakaan Bung Karno 17 Februari 2016. Blitar: UPT Perpustakaan Proklamator Bung Karno.

Tolkah. 2012. "Pembayaran Zakat Pada Badan Amil Zakat Dan Lembaga Amil Zakat Kaitannya Dengan Pajak Penghasilan." Majalah Ilmiah Widya, March, $22-27$.

Torgler, Benno. 2003. "The Importance of Faith: Tax Morale and Religiosity." Center for Research in economics, Management and the Arts (CREMA) 08:135 .

Triyuwono, Iwan. 2006. Perspektif, Metodologi, Dan Teori Akuntansi Syariah. PT. Raja Grafindo Persada.

Triyuwono, Iwan. 2009. "SEANDAINYA Refleksi Kesadaran Wajib Pajak Pribadi Dalam Perspektif Teori Kemanunggalan Dan Metafora Zakat." in Simposium Nasional Perpajakan II. Universitas Trunojoyo, 9-10 Desember 2009.

Triyuwono, Iwan. 2011. ""Sususaya" Melampaui Paradigma-Paradigma Metodologi Penelitian." Pp. 1-15 in Pelatihan Penelitian Kualitatif Two Days Workshop 
Center of Training for Research and Publication (CRP) Fakultas Ekonomi dan Bisnis Universitas Brawijaya 2-3 Oktober 2015. Malang.

Triyuwono, Iwan. 2015. "Taqwa: Deconstructing Triple Bottom Line (TBL) to Awake Human's Divine Consiusness." in 2nd Global Conference on Business and Social Science-2015, GCBSS-2015, 17-18 September 2015, Bali, Indonesia.

Widiastuti, Ni Putu Eka, Eko Ganis Sukoharsono, Gugus Irianto, dan Zaki Baridwan. 2015. "Yadnya - Hinduism Philosophy to Achieve Spiritual Awareness of SME Owners as Taxpayers: A Literary Discourse." International Journal of Business and Management Invention 4(5):38-43. 